\title{
EFFECT OF ORGANIC AND MINERAL SOIL FRACTIONS ON SORPTION BEHAVIOUR OF CHLOROPHENOL AND TRIAZINE MICROPOLLUTANTS
}

\author{
Sanja STIPIČEVIĆ, Sanja FINGLER, and Vlasta DREVENKAR \\ Institute for Medical Research and Occupational Health, Zagreb, Croatia \\ Received in June 2008 \\ Accepted in November 2008
}

\begin{abstract}
This article compares the sorption behaviour of 2,4,6-trichlorophenol, 2,3,4,6-tetrachlorophenol, pentachlorophenol, chlorotriazine atrazine, methylthiotriazine ametryn, methoxytriazine atratone, hydroxyatrazine, and didelakylated atrazine in a topsoil and an aquifer sediment before and after removal of sorbent organic matter and in humic acid. Freundlich isotherm coefficients $K_{\mathrm{f}}$ and $1 / n$ and free energy change $\left(\Delta G^{\circ}\right)$ were calculated for all compounds in all sorbents. According to sorbent $\mathrm{pH}$ values, chlorophenolate anions and uncharged triazine species dominated in all sorption experiments with topsoil and aquifer sediment. In experiments with humic acid, chlorophenols, atrazine, and didealkylated atrazine existed almost completely as neutral species, whereas protonated species dominated for hydroxyatrazine, atratone, and ametryn. In addition to a hydrophobic partition, sorption of all compounds in native soil and sediment sorbents includes specific, more polar interactions, which greatly depend on sorbate acidity/ basicity, specific properties of the sorbent organic matter and of mineral surface, as well as on the system $\mathrm{pH}$. A significantly greater sorption intensity of all compounds in "organic-free" than in the native aquifer sediment confirmed the importance and possible dominance of mineral surface in the sorption process. Sorption intensity of chlorophenol and triazine compounds in humic acid was closely related to compound hydrophobicity. Greater sorption of almost completely protonated hydroxyatrazine than of the more hydropohobic but uncharged atrazine indicated different humic acid reaction sites for two compounds and consequently different sorption mechanisms.
\end{abstract}

KEY WORDS: ametryn, atratone, atrazine, chlorophenolate anions, didealkylated atrazine, Freundlich isotherm, humic acid, hydroxyatrazine, mineral surface, organic matter

Partitioning and bioavailability of organic micropollutants in the environment depend to a great extent on their interactions with organic matter in water and soil as well as with mineral components of the soil. Sorption/desorption and degradation processes determine the mobility and persistence of organic pollutants in soils and sediments and their potential to contaminate ground and surface waters through leaching and run-off. Hydrophobic nonpolar compounds, e.g. persistent organochlorine pollutants and polycyclic aromatic hydrocarbons, are strongly sorbed in most soils/sediments, primarily due to hydrophobic interactions with insoluble (humin) and soluble (humic and fulvic acids) fractions of sorbent organic matter. Sorption mechanisms of less hydrophobic and ionisable micropollutants containing polar functional groups, such as many pesticides, may in addition to hydrophobic partitioning into sorbent organic matter include ion exchange interactions, hydrogen bond formation, interactions with metal cations, charge transfer, and covalent bonding $(1,2)$. The relative importance of organic micropollutant 
interactions with organic and inorganic sorbent fractions is closely related to the relative abundance of these two fractions in soils and sediments (3). Mineral components, especially clay minerals, may significantly influence the retention of organic compounds in soils with low organic matter content or if the sorbate is highly polar (4-7). Up-to-date studies of organic pollutant interactions with soil/ sediment components offer only a partial insight in possible sorption mechanisms, which is a consequence of sorbent's heterogeneous and insufficiently characterised active surface and of simultaneous action of several sorption mechanisms.

Chlorophenol pesticides and triazine herbicides as well as their degradation products belong to different classes of hydrophobic but ionisable environmental organic micropollutants. Hydrophobicity ( $n$-octanol/ water partition coefficients, $\left.K_{\text {ow }}\right)(8)$, water solubility (9-11), and acidity (8) of chlorophenols depend on the number of chlorine substituents (Table 1). At typical environmental $\mathrm{pH}$ values ( $\mathrm{pH}=7$ to 8 ), penta-, tetra-, and trichlorophenols are, according to their ionisation constants $(\mathrm{p} K$ ), regularly present in both molecular and phenolate form (Figure 1a). Therefore, their sorption intensity in soils and sediments highly depends on water-phase acidity and the degree of compound dissociation; more soluble chlorophenolates are sorbed to a lesser extent than the corresponding chlorophenols $(8,12-14)$. A strong correlation between sorbent organic matter content and the sorption intensity of neutral and ionised chlorophenol forms has been well documented $(8,15,16)$. Sorption experiments performed with terrestrial soils/sediments and marine sediments pointed to a different mechanism of sorption in marine and terrestrial sorbents (16). Organic matter sorption coefficients and free energy change obtained for the sorption of predominantly ionised tri-, tetra-, and pentachlorophenols in marine sorbents were significantly lower than those obtained for sorption in terrestrial sorbents. These results, as well as a significant deviation of Freundlich sorption isotherms from linearity, confirmed that the capacity of sorption was related not only to the amount but also to the type and origin of organic matter. The sorption intensity of chlorophenols is also influenced by the presence of charged species in the sorbent material (17) as well as by the ionic strength and $\mathrm{pH}$ of the aqueous phase controlling the stability of more hydrophilic phenolate forms $(8,12,13)$. Differences in free-energy change, enthalpies, and entropies calculated for sorption of ionised and neutral pentachlorophenol in a surface soil supported the conclusion that the neutral form was partitioned through hydrophobic interactions, whereas the ionised form was sorbed through more specific exothermic adsorption reactions, such as hydrogen bonding and charge transfer (14). A study of potential contributions of clay minerals and organic matter to pentachlorophenol retention in soils has shown that clay minerals also contribute to pentachlorophenol sorption, especially in the case when $\mathrm{K}^{+}$dominates as the exchangeable cation on the clay surfaces (5).

Symmetric triazine herbicides, with atrazine as the most prominent and the most extensively used representative, are weakly basic compounds (1820) of relatively high solubility in water, which depends on the substituent (- $\left.\mathrm{Cl},-\mathrm{OCH}_{3},-\mathrm{SCH}_{3}\right)$ in the 6-position of the triazine ring (Table 1). Water solubility of triazine herbicides increases as follows: chlorotriazines $<$ methylthiotriazines $<$ methoxytriazines $(9,21)$. As indicated by $K_{\text {ow }}$ coefficients, methylthiotriazines are more lipophilic than chlorotriazines and methoxytriazines with the same substituents in the 2- and 4-position of the triazine ring $(22,23)$. In aqueous solutions, triazines exist in either neutral or protonated form, depending on the $\mathrm{p} K_{\mathrm{a}}$ of the compound and on the $\mathrm{pH}$ of the system. The ring nitrogen atom, located in the 3-position between the electron-rich alkyl-side chains, is the most basic and hence the most likely site of protonation (Figure 1b) (24). The main degradation reactions of triazine herbicides are dechlorination, dealkylation, and oxidation. Hydroxylated degradation products such as hydroxyatrazin are more basic than parent compounds. Sorption of triazines by organic and mineral soil fractions involve different physical and chemical mechanisms due to the coexistence of heterogeneous sorption sites on each soil component, and the sorption intensity is related to the intrinsic characteristics of triazine compounds: structure, lipophilicity, and ionisation constants (25). The primary binding mechanism of less basic triazines $\left(\mathrm{p} K_{\mathrm{a}}\right.$ near 2 ) are hydrophobic interactions, while more basic triazines ( $K_{\mathrm{a}}$ values $>4$ ) are sorbed more intensively due to the mixed-mode binding to clays and soil organic matter (26).

The aim of this study was to compare the sorption behaviour of three chlorophenols: 2,4,6trichlorophenol (TCP), 2,3,4,6-tetrachlorophenol (TeCP), and pentachlorophenol (PCP), and of differently substituted triazine compounds: chlorotriazine atrazine, methylthiotriazine ametryn, methoxytriazine atratone, and atrazine degradation 
products hydroxyatrazine and didelakylated atrazine (DDA) in humic acid and in samples of a topsoil and an aquifer sediment before and after removal of sorbent organic matter.

\section{MATERIALS AND METHODS}

\section{Chemicals}

Triazine herbicides: atratone (6-methoxy- $N$ ethyl- $N$ '-isopropyl-[1,3,5] triazine-2,4-diamine), atrazine (6-chloro- $N$-ethyl- $N$ '-isopropyl$[1,3,5]$ triazine-2,4-diamine), and ametryn (6-methylthio- $N$-ethyl- $N$ '-isopropyl-[1,3,5] triazine-2,4diamine), and two atrazine degradation products: deethyldeisopropylatrazine (6-chloro-[1,3,5]triazine2,4-diamine) and hydroxyatrazine (6-hydroxy- $\mathrm{N}$ ethyl- $N$ '-isopropyl-[1,3,5] triazine-2,4-diamine) were purchased as standards of $95.0 \%$ to $99.9 \%$ purity from Riedel de Haën (Seelze, Germany). 2,4,6-Trichlorophenol, 2,3,4,6-tetrachlorophenol, and pentachlorophenol, all of p.a. purity, were the products of H.P. Chem Service (West Chester, PA, USA). 2,4,6-Tribromophenol (p.a.) and acetic acid anhydride (p.a.) were the products of Fluka A.G. (Buchs, Switzerland). Sep-Pak $\mathrm{C}_{18}$ silica cartridges were from Waters Associates (Milford, MA, USA). HPLC-grade acetonitrile and $n$-hexane for organic trace analysis (p.a.) were the products of Merck (Darmstadt, Germany). Deionised water $\left(4 \mu \mathrm{S} \mathrm{cm}^{-1}\right)$ from a Millipore Milli-Q water purification system (Bedford, MA, USA) was used to prepare all aqueous solutions for HPLC analyses. All other chemicals and organic solvents of analytical grade were supplied by Kemika (Zagreb, Croatia).

\section{Sorbent samples}

One topsoil sample and one subsurface aquifer sediment sample were collected at a depth of $0.1 \mathrm{~m}$ and $14.1 \mathrm{~m}$, respectively, in a semirural area in the northwest Croatia, next to a drinking water well field. Granulometric characteristics, mineral composition, organic matter content, and specific surface area were determined as described earlier (15). The topsoil and aquifer sediment were of sandy gravel and clayey silt type, with a clay fraction of $7.58 \%$ and $37.99 \%$, respectively. To prepare "organic-free" sorbents, aliquots of native topsoil and aquifer sediment were treated with $\mathrm{H}_{2} \mathrm{O}_{2}$ (15). The acidities of native and "organic-free" topsoil and aquifer sediment were measured with a glass electrode in the supernatant of samples prepared by overnight equilibration of $0.5 \mathrm{~g}$ air-dried sorbents with $3 \mathrm{~cm}^{3}$ of deionised water. Sorbent properties are listed in Table 2. For sorption experiments, air-dried sorbents were sieved through a $1 \mathrm{~mm}$ sieve and refrigerated at $4{ }^{\circ} \mathrm{C}$ until use.

A sample of humic acid was obtained through the courtesy of Professor Alessandro Piccolo, Department of Agricultural Chemistry, University of Naples "Federico II", Portici, Italy. The humic acid was analysed for elemental composition with the following results: C $58.79 \%$, H $3.92 \%$, N $1.57 \%$, S $3.77 \%$, and $\mathrm{Cl} 1.67 \%$. The oxygen content of $30.28 \%$ was calculated as the difference from $100 \%$. The ash content was $4.22 \%$. The calculated atomic ratios were 0.80 for $\mathrm{H} / \mathrm{C}$ and 0.39 for $\mathrm{O} / \mathrm{C}$. UV-Visible spectrum of humic acid was taken between $200 \mathrm{~nm}$ and $800 \mathrm{~nm}$ using a Varian Cary 300 Conc UV-Visible spectrophotometer (Walnut Creek, USA). Humic acid was dissolved in $0.1 \mathrm{~mol} \mathrm{dm}^{-3} \mathrm{NaOH}(\mathrm{pH} 12.8)$ at mass concentration of $80 \mu \mathrm{g} \mathrm{cm}^{-3}$, and the spectral

Table 1 Properties of investigated sorbates: aqueous solubility at $22{ }^{\circ} \mathrm{C}(9-11)$, ionisation constant $p K$ (8,18-20), and lipophilicity expressed by partition coefficient $K_{\text {ow }}$ in n-octanol/water for triazines and in n-octanol/0.01 mol dm $\mathrm{m}^{-3} \mathrm{HCl}$ for chlorophenols $(8,22,23)$

\begin{tabular}{lccc}
\hline Compound & $\begin{array}{c}\text { Aqueous solubility / } \\
\mathbf{m g ~ d m}^{-3}\end{array}$ & $\mathbf{p} \boldsymbol{K}_{\mathbf{a}}$ & $\log \boldsymbol{K}_{\text {ow }}$ \\
\hline DDA & - & 1.5 & 0.18 \\
Hydroxyatrazine & 6 & 5.2 & 1.03 \\
Atratone & 1800 & 4.2 & 2.69 \\
Atrazine & 33 & 1.7 & 2.48 \\
Ametryn & 200 & 4.0 & 3.07 \\
TCP & $4 \times 10^{-3}$ & 6.2 & 3.72 \\
TeCP & $8 \times 10^{-4}$ & 5.4 & 4.42 \\
PCP & $5 \times 10^{-7}$ & 5.3 & 5.24 \\
\hline
\end{tabular}

- data not found 
a)<smiles>Oc1ccc(Cl)cc1</smiles>

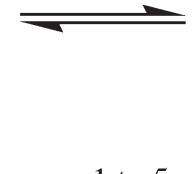<smiles>[O-]c1ccc(Cl)cc1</smiles>

b)<smiles>[R]Nc1nc([X])nc(N[R2])n1</smiles>

Figure 1 Neutral and ionised form of a) chlorophenols and b) symmetric triazine compounds

absorbances were measured at $254 \mathrm{~nm}, 436 \mathrm{~nm}, 465$ $\mathrm{nm}$, and $665 \mathrm{~nm}$ after equilibrating the solution for 24 $\mathrm{h}, 48 \mathrm{~h}$, and $72 \mathrm{~h}$ at room temperature. The ratios of the measured spectral absorbances $\left(A_{254} / A_{436}\right.$ and $\left.A_{465} / A_{665}\right)$ were calculated for spectroscopic characterisation of humic acid (27-29).

The acidity of humic acid was determined by measuring the $\mathrm{pH}$ in the supernatant of samples prepared by overnight equilibration of $0.025 \mathrm{~g}$ (in experiments with chlorophenols) or $0.010 \mathrm{~g}$ (in experiments with triazines) of sorbent with $3 \mathrm{~cm}^{3}$ of deionised water. The $\mathrm{pH}$ of humic acid suspension was 3.8 and 3.3 in sorption experiments with triazines and chlorophenols, respectively.

\section{Sorption experiments}

Standard stock solutions of investigated sorbates were prepared in acetonitrile, acetone, or water, and further diluted with aqueous solution of $0.01 \mathrm{~mol}$ $\mathrm{dm}^{-3} \mathrm{CaCl}_{2}$. Sorption experiments were run separately

Table 2 Properties of native and "organic-free" topsoil and aquifer sediment samples

\begin{tabular}{|c|c|c|c|c|}
\hline Sorbent & Organic matter / \% & $\begin{array}{c}\text { Specific surface } \\
\text { area } / \mathrm{m}^{2} \mathrm{~g}^{-1}\end{array}$ & $\begin{array}{l}\text { Mean particle } \\
\text { size / } \mu \mathrm{m}\end{array}$ & pH (in water) \\
\hline \multicolumn{5}{|l|}{$\overline{\text { Native }}$} \\
\hline Topsoil $^{\mathrm{a}}$ & 7.7 & 2.6 & 493 & 6.8 \\
\hline Aquifer sediment $\mathrm{t}^{\mathrm{b}}$ & 8.4 & 24.9 & 6 & 7.2 \\
\hline \multicolumn{5}{|l|}{ "Organic-free" } \\
\hline Topsoil $^{\mathrm{a}}$ & & 4.9 & 493 & 9.0 \\
\hline Aquifer sediment $t^{b}$ & & 53.0 & 6 & 6.6 \\
\hline
\end{tabular}

${ }^{a, b}$ Dominant mineral species present in decreasing order:

a quartz, dolomite, calcite, feldspars, chlorite.

${ }^{b}$ montmorillonite, quartz, micas, chlorite. 
with a mixture of triazine compounds and a mixture of chlorophenols in duplicate for each sorbent at five concentrations ranging from $0.28 \mathrm{nmol} \mathrm{cm}^{-3}$ to $4.22 \mathrm{nmol} \mathrm{cm}^{-3}$ for triazines and from $0.05 \mathrm{nmol} \mathrm{cm}^{-3}$ to $0.72 \mathrm{nmol} \mathrm{cm}^{-3}$ for chlorophenols.

After overnight equilibration of $0.5 \mathrm{~g}$ of soil/ sediment sorbents (native and "organic-free") and $0.010 \mathrm{~g}$ (in sorption experiments with triazines) or $0.025 \mathrm{~g}$ (in sorption experiments with chlorophenols) of humic acid with $3 \mathrm{~cm}^{3}$ of deionised water, the samples were centrifuged at $425 \mathrm{G}$ for $10 \mathrm{~min}$, and the aqueous phase was decanted. A $10.5 \mathrm{~cm}^{3}$ volume of chlorophenol solution or $10.0 \mathrm{~cm}^{3}$ volume of triazine solution, prepared in $0.01 \mathrm{~mol} \mathrm{dm}^{-3} \mathrm{CaCl}_{2}$, was added to the water-saturated sorbent. To achieve the equilibrium, the suspensions were agitated on a mechanical shaker for $24 \mathrm{~h}$ at room temperature. The supernatant was carefully decanted after centrifugation of samples for $5 \mathrm{~min}$ at $425 \mathrm{G}$ and then filtered through a $0.45 \mu \mathrm{m}$ Teflon filter.

The equilibrium concentrations of triazine compounds in the aqueous phase were determined by high performance liquid chromatographic analysis of filtered supernatant using a Varian ProStar 230 SDM liquid chromatograph (Walnut Creek, USA), equipped with Varian ProStar 410 autosampler, a $100 \mathrm{~mm}^{3}$ sample loop, and Varian ProStar 330 multichannel diode-array detector (DAD) set at $213 \mathrm{~nm}$ and $221 \mathrm{~nm}$. The chromatographic column was Thermo Hypersil octadecyl-modified silica, $250 \mathrm{~mm} \times 4.6 \mathrm{~mm}$ I.D., with $5 \mu \mathrm{m}$ sized particles (Bellefonte, PA, USA). The mobile phase consisted of acetonitrile and $0.01 \mathrm{~mol} \mathrm{dm}^{-3}$ phosphate buffer, $\mathrm{pH}$ 7. The gradient elution programme started with $5 \%$ of acetonitrile for $3 \mathrm{~min}$, and continued from $5 \%$ to $90 \%$ of acetonitrile over $7 \mathrm{~min}$. The mobile phase flow-rate was $1 \mathrm{~cm}^{3} \mathrm{~min}^{-1}$. Aqueous solutions of triazines prepared in $0.01 \mathrm{~mol} \mathrm{dm}^{-3} \mathrm{CaCl}_{2}$ were used as external standards for quantitative analysis.

The equilibrium concentrations of non-sorbed chlorophenols in aqueous phase were determined by $\mathrm{C}_{18}$ solid-phase extraction of analytes from $5 \mathrm{~cm}^{3}$ aliquots of clear supernatant. Chlorophenols retained on a Sep-Pak $\mathrm{C}_{18}$ cartridge were eluted with $1.5 \mathrm{~cm}^{3}$ of acetone and then acetylated for gas chromatographic analysis with acetic acid anhydride as described earlier (15). 2,4,6-Tribromophenol was used as internal standard. The samples were analysed with a Varian Aerograph Series 1400 gas chromatograph equipped with $\mathrm{Sc}{ }^{3} \mathrm{H}$ electron capture detector. A glass chromatographic column,
$1.8 \mathrm{~m} \times 2 \mathrm{~mm}$ I.D., was packed with $1.3 \%$ Silicone GE SF $96+5.3 \%$ QF 1 on (0.13 to 0.16$) \mathrm{mm}$ Supelcoport. The carrier gas was nitrogen with a flow-rate of $30 \mathrm{~cm}^{3}$ $\mathrm{min}^{-1}$. Column, injector, and detector temperatures were $160{ }^{\circ} \mathrm{C}, 240{ }^{\circ} \mathrm{C}$, and $270{ }^{\circ} \mathrm{C}$, respectively. The standards for gas chromatographic analysis were prepared by dissolving chlorophenols in acetone, and by subsequent acetylation using the same procedure as for the samples.

The equilibrium amounts of triazine and chlorophenol compounds sorbed per unit of sorbent mass $\left(x / m\right.$ in $\left.\mathrm{nmol} \mathrm{g}^{-1}\right)$ were calculated as the difference between the initial and equilibrium $\left(C_{\mathrm{e}}\right.$ in $\left.\mathrm{nmol} \mathrm{cm} \mathrm{cm}^{-3}\right)$ concentrations of compounds in the aqueous phase. Experimental data sets for each pair of sorbate and sorbent were fitted by non-linear regression to the Freundlich sorption isotherm curve:

$$
x / m=K_{f} C_{e}^{l / n}
$$

where $K_{\mathrm{f}}$ is the sorption coefficient indicating sorption intensity and $1 / n$ is constant for a given compound and sorbent that reflects isotherm linearity. Coefficients $K_{\mathrm{f}}$ were used for the calculation of free-energy changes of sorption according to the equation $\Delta G^{\circ}=-R T \ln K_{\mathrm{f}}$, where $R$ is gas constant, and $T$ is absolute temperature. All experiments were performed at $295 \mathrm{~K}$.

\section{RESULTS AND DISCUSSION}

Characteristics of the topsoil and aquifer sediment samples before (native sorbents) and after removal of organic phase ("organic-free" sorbents) by $\mathrm{H}_{2} \mathrm{O}_{2}$ treatment are summarised in Table 2. Mineralogical analysis showed that quartz and carbonate minerals calcite and dolomite were dominant mineral species in the topsoil. The aquifer sediment was dominated by clay minerals, and the most abundant was montmorillonite. Native sorbents were similar in organic matter content but significantly different in specific surface area (SSA); the SSA of the aquifer sediment was for one order of magnitude greater than of the topsoil SSA. The SSA of "organic-free" sorbents doubled compared to the native sorbents. Removal of organic phase also affected sorbent $\mathrm{pH}$ values. The native sorbents were neutral, but the "organic-free" topsoil became strongly alkaline. The $\mathrm{pH}$ value of the aquifer sediment slightly decreased by the removal of organic phase, but the "organic-free" sorbent could still be classified as neutral. 
The elemental composition of humic acid used in this study is quite similar to the average percentages reported for elemental composition of soil humic acids (28). UV-Visible spectral absorbances of humic acid and their ratios at particular wavelengths are shown in Table 3. After a $48 \mathrm{~h}$ equilibration at $\mathrm{pH} 12.8$, the variability in spectroscopic data was very low, indicating the stabilisation of humic acid structure in solution. The ratio of absorbances at $465 \mathrm{~nm}$ and $665 \mathrm{~nm}\left(A_{465} / A_{665}\right)$ is used as a measure of aromaticity or humification: a low ratio $(\sim 3.0)$ indicates a high aromatic character, and a high ratio $(\sim 8)$ a high aliphatic character of humic acid; humification is indicated by lower $A_{465} / A_{665}$ ratio (28). Absorption of light at $254 \mathrm{~nm}$ reflects the presence of UVabsorbing functional groups and absorption at $436 \mathrm{~nm}$ of the coloured (yellow/brown) ones. Humic acids characterised by higher UV-absorption and higher $A_{254} / A_{436}$ absorbance ratio are expected to be relatively rich in aromatic structures and carbonylic, carboxylic, and phenolic functional groups (27).

The fractions of ionised sorbates were calculated from compound $\mathrm{p} K$ values and the $\mathrm{pH}$ of the system (8). Ionised forms of chlorophenols dominated in all sorption experiments with the native and "organicfree" topsoil and aquifer sediment: TeCP and PCP were almost fully ionised (94\% to $100 \%$ ), and fractions of ionised TCP were $80 \%$ in the native and $100 \%$ in the "organic-free" topsoil, and $91 \%$ in the native and $72 \%$ in the "organic-free" aquifer sediment. Under the same conditions, triazine sorbates were not ionised at all, save for negligible fractions of the most basic hydroxyatrazine in suspension of both native sorbents (1\% to $2 \%)$ and in the "organic-free" aquifer sediment $(4 \%)$. In experiments with humic acid under acidic conditions, the three chlorophenols, atrazine, and didealkylated atrazine were almost completely ( $>99 \%$ ) neutral, whereas protonated species dominated for hydroxyatrazine (96\%), atratone (72\%), and ametryn (61\%).

The results of sorption experiments are summarised in Table 4, showing the Freundlich sorption coefficients $K_{\mathrm{f}}$ and $1 / n$ for each sorbate in native and "organic-free" topsoil and aquifer sediment and in humic acid. As discussed above and reported previously (15), the results obtained for the sorption of chlorophenols in soil and sediment sorbents referred to the sorption of chlorophenolates. The $K_{\mathrm{f}}$ coefficients, reflecting the sorption intensity, were for all chlorophenol species about 15 to 35 times higher in the native topsoil than in the native aquifer sediment, despite very similar organic matter content of these two sorbents.

Table 3 Specific spectral absorbances and their ratios for humic acid dissolved in $0.1 \mathrm{~mol} \mathrm{dm}^{-3} \mathrm{NaOH}$ (pH 12.8) at mass concentration of $80 \mu \mathrm{g} \mathrm{cm}^{-3}$

\begin{tabular}{lcccccc}
\hline \multirow{2}{*}{$\begin{array}{l}\text { Time of } \\
\text { equilibration / h }\end{array}$} & $\mathbf{2 5 4} \mathbf{~ n m}$ & $\mathbf{4 3 6} \mathbf{~ n m}$ & $\mathbf{4 6 5} \mathbf{~ n m}$ & $\mathbf{6 6 5} \mathbf{~ n m}$ & $\boldsymbol{A}_{\mathbf{2 5 4}} / \boldsymbol{A}_{\mathbf{4 3 6}}$ & $\boldsymbol{A}_{\mathbf{4 6 5}} / \boldsymbol{A}_{\mathbf{6 6 5}}$ \\
\hline 24 & 3.86 & 1.17 & 0.93 & 0.19 & 3.30 & 4.89 \\
48 & 3.77 & 1.13 & 0.89 & 0.17 & 3.34 & 5.24 \\
72 & 3.76 & 1.09 & 0.86 & 0.16 & 3.45 & 5.38 \\
\hline
\end{tabular}

Table 4 Freundlich isotherm coefficients $K_{f}$ and $1 / n$ for sorption of triazine and chlorophenol species in native and "organicfree" topsoil and aquifer sediment and in humic acid

\begin{tabular}{|c|c|c|c|c|c|c|c|c|c|c|}
\hline \multirow{3}{*}{ Sorbate } & \multicolumn{4}{|c|}{ Native sorbents } & \multicolumn{4}{|c|}{ "Organic-free" sorbents } & \multirow{2}{*}{\multicolumn{2}{|c|}{ Humic acid }} \\
\hline & \multicolumn{2}{|c|}{ Topsoil } & \multicolumn{2}{|c|}{ Aquifer sediment } & \multicolumn{2}{|c|}{ Topsoil } & \multicolumn{2}{|c|}{ Aquifer sediment } & & \\
\hline & $K_{\mathrm{f}}$ & $1 / \mathbf{n}$ & $K_{\mathrm{f}}$ & $1 / \mathbf{n}$ & $K_{\mathrm{f}}$ & $1 / n$ & $K_{\mathrm{f}}$ & $1 / n$ & $K_{\mathrm{f}}$ & $1 / \mathbf{n}$ \\
\hline $\mathrm{DDA}$ & 5.36 & 0.77 & 2.57 & 0.65 & 2.02 & 0.35 & 4.79 & 0.47 & 203.16 & 1.08 \\
\hline Hydroxyatrazine & 20.57 & 0.52 & 145.99 & 0.65 & 26.53 & 0.38 & $2169.60 *$ & $0.65^{*}$ & 1121.00 & 0.76 \\
\hline Atratone & 9.55 & 0.81 & 44.55 & 0.31 & 8.57 & 0.58 & 147.99 & 0.41 & 1892.50 & 0.97 \\
\hline Atrazine & 9.91 & 0.88 & 4.03 & 0.66 & 0.78 & 1.26 & 39.99 & 0.41 & 325.86 & 0.79 \\
\hline Ametryn & 20.54 & 0.86 & 34.28 & 0.34 & 5.20 & 0.50 & 582.87 & 0.95 & 4781.60 & 1.09 \\
\hline TCP & 15.03 & 0.72 & 0.97 & 0.29 & 0.29 & -0.01 & 12.87 & 0.41 & 718.78 & 0.77 \\
\hline $\mathrm{TeCP}$ & 26.32 & 0.80 & 0.92 & 0.41 & 0.04 & -0.31 & 7.73 & 0.46 & 1986.80 & 0.95 \\
\hline PCP & 43.10 & 0.75 & 1.20 & 0.45 & 0.13 & -0.09 & 13.56 & 0.45 & 2410.96 & 0.80 \\
\hline
\end{tabular}

* sorption experiments performed with $0.1 \mathrm{~g}$ of sorbent and with initial concentrations of sorbate ranging from $3.26 \mathrm{nmol} \mathrm{cm}^{-3}$ to $32.62 \mathrm{nmol} \mathrm{cm}^{-3}$ 
Differences in sorption capacity indicated that hydrophobic partition depends not only on the amount of organic matter, but also on the type of organic substances attached to the natural sorbent material. Organic substances in the topsoil and in the aquifer sediment at a depth of $14.1 \mathrm{~m}$ are probably different in their structure, functionality and, consequently, reactivity. The $K_{\mathrm{f}}$ values in the native topsoil increased with chlorophenol hydrophobicities, but this was not the case with the native aquifer sediment, where all chlorophenolates were sorbed almost equally. The removal of organic matter from the topsoil sorbent significantly decreased the sorption intensity of all three chlorophenolates; the $K_{\mathrm{f}}$ values dropped for two to three orders of magnitude. The very weak sorption interactions indicate a very low sorption capacity of the topsoil mineral surface. The values of $1 / n$ coefficient reflecting the isotherm shape were small and negative, confirming that the "organic-free" topsoil was easily saturated at low chlorophenolate concentrations. Contrary to the topsoil the sorption intensity of chlorophenolates in the aquifer sediment drastically increased after the removal of organic phase. In the "organic-free" aquifer sediment, the $K_{\mathrm{f}}$ values of the three chlorophenolates were about 8 to 13 times higher than in the native sorbent. These results indicate much stronger interactions of chlorophenolates with surfaces rich in clay minerals than with the covering organic phase. As no partition was possible after the removal of organic phase, there was no correlation between $K_{\mathrm{f}}$ values and sorbate hydrophobicities. The sorption coefficients of TCP and PCP were almost equal and were twice as high as the $\mathrm{TeCP}$ coefficient. A strong interaction of chlorophenolates with mineral surface in this sorbent could be a consequence of abundance in clay minerals, especially montmorillonite, which has a very large SSA (up to $850 \mathrm{~m}^{2} \mathrm{~g}^{-1}$ ).

Triazine compounds demonstrated quite a different sorption behaviour in the native topsoil and aquifer sediment than chlorophenols. While chlorophenols were sorbed in the aquifer sediment to a much lesser extent than in the topsoil, triazine sorption coefficients in these two sorbents were of the same order of magnitude or even one order of magnitude greater in the aquifer sediment. In both sorbents, the highest $K_{\mathrm{f}}$ values were calculated for the most basic hydroxyatrazine and the lowest for the least basic and the most hydrophilic didealkylated atrazine. Save for hydroxyatrazine, the sorption intensity in the native topsoil was related to sorbate hydrophobicity and increased with increasing $K_{\text {ow }}$ coefficients. In the native aquifer sediment, the sorption intensity strictly followed the increase in sorbate basicity ( $\mathrm{p} K$ values) and increased in the following order: DDA $<$ atrazine $<$ ametryn $<$ atratone $<$ hydroxyatrazine. The removal of organic phase from the topsoil decreased the sorption intensity of atrazine for one order: of magnitude. This decrease was also observed for didealkylated atrazine (for a factor of 2) and ametryn (for a factor of 4), while atratone and hydroxyatrazine were sorbed to a similar extent as in the native topsoil. However, similar to the results obtained for chlorophenols, the sorption intensity of all triazine compounds in the "organic-free" aquifer sediment was significantly greater than in the native sorbent. The $K_{\mathrm{f}}$ values increased for one order of magnitude for all sorbates, save for didealkylated atrazine whose sorption intensity doubled. More basic methoxytriazines and methylthiotriazines were sorbed more intensively than atrazine. The greatest sorption was observed for hydroxyatrazine. Under conditions applied in soil and sediment sorption experiments - sorbent mass $0.5 \mathrm{~g}$ and initial hydroxyatrazine concentration ranging from $0.32 \mathrm{nmol} \mathrm{cm}^{-3}$ to $3.04 \mathrm{nmol} \mathrm{cm}^{-3}$ - the equilibrium concentrations of hydroxyatrazine in aqueous phase were not measurable due to almost complete sorption of the compound in the "organic-free" sorbent. Therefore, in the repeated experiment (results shown in Table 4), sorbent mass was lowered to $0.1 \mathrm{~g}$ and sorbate initial concentrations were increased to $(3.26$ to 32.62$) \mathrm{nmol} \mathrm{cm}^{-3}$.

The Freundlich sorption coefficient $1 / n$ was considerably lower than unity for hydroxyatrazine in the native topsoil and for all triazine compounds in the native aquifer sediment. The lack of isotherm linearity $(1 / n<0.8)$ was also observed for all triazines in the "organic-free" sorbents, save for atrazine in the "organic-free" topsoil and ametryn in the "organicfree" aquifer sediment. This finding shows limited sorbent sorption capacity in the studied range of sorbate concentrations, and suggests that sorption in native sorbents was governed by other mechanisms in addition to simple partition into organic phase.

The sorption of chlorophenols in humic acid referred to neutral species that are sorbed to a greater extent than corresponding anions. Sorption intensity increased with the hydrophobicity of the compounds and sorption isotherms were nearly linear. The sorption intensity of chlorotriazine, methoxytriazine, and methylthiotriazine compounds also increased with compound hydrophobicity, in the following order: DDA<atrazine $<$ atratone $<$ ametryn. However, 
hydroxyatrazine, almost completely in protonated form, was sorbed to a much greater extent than the more hydrophobic and neutral atrazine, but less than the predominantly protonated atratone and ametryn. Similar differences in sorption intensity of hydroxyatrazine and atrazine in humic acid were reported by Moreau-Kervevan and Mouvet (25), who explained that charge transfer, as a mechanism of triazine sorption in humic acid, could be enhanced for hydroxyatrazine by replacing the chlorine substituent in the atrazine with a the more electronegative hydroxylic group. In addition, hydroxyatrazine sorption could be enhanced by ionic bonding between the protonated species and the ionised acidic groups in humic acid. Ionisation of acidic groups in humic acid depends on solution $\mathrm{pH}$, and influences the sorption mechanisms of all triazine compounds. These authors also investigated the sorption of hydroxyatrazine and atrazine in clay minerals kaolinite and smectite, and discussed possible causes of greater hydroxyatrazine sorption. Hydrogen bonding, protonation, and cationic adsorption have been suggested as sorption mechanisms contributing to the greater sorption intensity of hydroxyatrazine than of the less basic atrazine.

Table 5 compares the changes in free energy during the sorption of chlorophenol and triazine compounds in the native and "organic-free" soil and sediment samples and in humic acid. Differences in $\Delta G^{\circ}$ values suggest different sorption mechanisms. Most $\Delta G^{\circ}$ values are negative, which indicates that spontaneous sorption process and greater sorption intensities are followed by greater $-\Delta G^{\circ}$. Consequently, the highest $-\Delta G^{\circ}$ values were calculated for all compounds in humic acid, showing the ability of sorbates to develop polar interactions with polar sorbent groups. Higher values of free energy change ranging from $-12 \mathrm{~kJ} \mathrm{~mol}^{-1}$ to $-19 \mathrm{~kJ} \mathrm{~mol}^{-1}$ were also established for the sorption of hydroxyatrazine in the native and "organic-free" aquifer sediment and for the sorption of ametryn and atratone in the latter sorbent. In all sorbents, save for the native topsoil, free energy change for the sorption of atrazine was lower than the values calculated for more basic ametryn, atratone, and hydroxyatrazine. This suggests differences in the sorption mechanisms of triazine compounds with different substituent at the 6-position of triazine ring. This finding is in good agreement with differences in free energy changes reported for the sorption of chlorotriazines and methylthiotriazines in reference EURO-Soils (30).

\section{CONCLUSIONS}

In addition to hydrophobic partition, the sorption of both chlorophenol and triazine compounds in native soil and sediment sorbents investigated in this study includes specific, more polar interactions that greatly depend on sorbate acidity/basicity, specific profile of sorbent organic matter, and sorbent mineral surface as well as on the system $\mathrm{pH}$ value. The most likely sorption mechanisms are hydrogen bonding, charge transfer, ionic bonding, and for triazines cationic adsorption of the protonated species. A significantly greater sorption intensity of all compounds in the "organic-free" than in the native aquifer sediment confirmed the importance and possible dominance of mineral surfaces rich in clay minerals, especially in montmorillonite, in the process of sorption. The sorption intensity of three chlorophenols and of

Table 5 Free-energy change $\left(\Delta G^{\circ}\right)$ for the sorption of triazine and chlorophenol species in different types of sorbents

\begin{tabular}{|c|c|c|c|c|c|}
\hline \multirow{3}{*}{ Sorbate } & \multicolumn{5}{|c|}{$-\Delta G^{\circ} / \mathbf{k J ~ m o l}^{-1}$} \\
\hline & \multicolumn{2}{|c|}{ Native sorbents } & \multicolumn{2}{|c|}{ "Organic-free" sorbents } & \multirow{2}{*}{ Humic acid } \\
\hline & Topsoil & Aquifer sediment & Topsoil & Aquifer sediment & \\
\hline DDA & 4 & 1 & 2 & 4 & 13 \\
\hline Hydroxyatrazine & 7 & 12 & 8 & 19 & 17 \\
\hline Atratone & 6 & 9 & 5 & 12 & 18 \\
\hline Atrazine & 6 & 3 & -1 & 9 & 14 \\
\hline Ametryn & 7 & 9 & 4 & 16 & 21 \\
\hline TCP & 7 & -0.1 & -3 & 6 & 16 \\
\hline ТeCP & 8 & -0.2 & -8 & 5 & 19 \\
\hline РCP & 9 & 0.5 & -5 & 6 & 19 \\
\hline
\end{tabular}

$\Delta G^{\circ}=-R T \ln K_{f} ; R$ is gas constant, $T$ is absolute temperature, and $K_{f}$ is Freundlich sorption coefficient 
chlorotriazine, methylthiotriazine, and methoxytriazine compounds in humic acid was closely related to compound hydrophobicity. The greater sorption of almost completely protonated hydroxyatrazine than of the more hydrophobic but uncharged atrazine indicated different humic acid reaction sites for the two compounds, and consequently different sorption mechanisms.

\section{Acknowledgement}

This work was supported by the Ministry of Science and Technology of the Republic of Croatia through the Project 022-0222882-2896 "Organic micropollutants in the environment - distribution, interactions, human exposure".

\section{REFERENCES}

1. Calvet R. Adsorption of organic chemicals in soils. Environ Health Perspect 1989;83:145-77.

2. Aboul-Kassim TAT, Simoneit BRT. Pollutant-Solid Phase Interactions: Mechanisms, Chemistry and Modelling. Berlin Heidelberg: Springer-Verlag; 2001. p. 107-67.

3. Spark KM, Swift RS. Effect of soil composition and dissolved organic matter on pesticide sorption. Sci Total Environ 2002;298:147-61.

4. Roy WR, Krapac IG. Adsorption and desorption of atrazine and deethylatrazine by low organic carbon geologic materials. J Environ Qual 1994;23:549-56.

5. He Y, Xu J, Wang H, Zhang Q, Muhammad A. Potential contributions of clay minerals and organic matter to pentachlorophenol retention in soils. Chemosphere 2006;65:497-505.

6. Bandara J, Mielczarski JA, Kiwi J. Adsorption mechanisms of chlorophenols on iron oxides, titanium oxide and aluminium oxide as detected by infrared spectroscopy. Appl Catal B 2001;34:307-20.

7. Herwig U, Klump E, Narres H-D, Schwuger MJ. Physicochemical interactions between atrazine and clay minerals. Appl Clay Sci 2001;18:211-22.

8. Schellenberg K, Leuenberger C, Schwarzenbach RP. Sorption of chlorinated phenols by natural sediments and aquifer materials. Environ Sci Technol 1984;18:652-7.

9. Shiu WY, Ma KC, Mackay D, Seiber JN, Wauchope RD Solubilities of pesticide chemicals in water. Part II: Data compilation. Rev Environ Contam Toxicol 1990;116:15187.

10. Leuenberger C, Ligocki MP, Pankow JF. Trace organic compounds in rain. 4. Identities, concentrations, and scavenging mechanisms for phenols in urban air and rain. Environ Sci Technol 1985;19:1053-8.

11. World Health Organization (WHO). Pentachlorophenol. Environmental Health Criteria No. 71. Geneva: WHO; 1987.

12. Lagas P. Sorption of chlorophenols in the soil. Chemosphere 1988; $17: 205-16$

13. Westal JC, Leuenberger C, Schwarzenbach RP. Influence of $\mathrm{pH}$ and ionic strength on aqueous-nonaqueous distribution of chlorinated phenols. Environ Sci Technol 1985;19:193-8.
14. DiVincenzo JP, Sparks DL. Sorption of neutral and charged forms of pentachlorophenol on soil:evidence for different mechanisms. Arch Environ Contam Toxicol 2001;40:44550.

15. Fröbe Z, Fingler S, Drevenkar V, Juračić M. Sorption behaviour of some chlorophenols in natural sorbents. 1 . Validity of the partition model for sorption of phenolates. Sci Total Environ 1994;155:199-213.

16. Fingler S, Drevenkar V, Fröbe Z. Sorption of chlorophenolates in soils and aquifer and marine sediments. Arch Environ Contam Toxicol 2005;48:32-9.

17. Schwarzenbach RP, Gschwend PM, Imboden DM. Environmental Organic Chemistry. New York: Wiley; 1993. p. 255-341.

18. Prosen H, Zupančič-Kralj L, Marsel J. Optimization of an analytical procedure for the determination of triazine herbicides in environmental samples. J Chromatogr A 1995;704:121-30.

19. Weber JB. The triazine herbicides. Res Rev 1970;32:99118.

20. Loos R, Niessner R. Analysis of atrazine, terbutylazine and their $\mathrm{N}$-dealkylated chlor and hydroxyl metabolites by solidphase extraction and gas chromatography-mass spectrometry and capillary electrophoresis-ultraviolet detection. J Chromatogr A 1999;835:217-29.

21. Sabik H, Jeannot R, Rondeau B. Multiresidue methods using solid-phase extraction techniques for monitoring priority pesticides, including triazines and degradation products, in ground and surface waters. J Chromatogr A 2000;885:21736.

22. Fröbe Z, Štengl B, Lovrec I, Drevenkar V. n-Octanol/water partition coefficients and sorption behaviour of triazine herbicides and some of their degradation products. In: Proceedings of the COST 66 Workshop "Pesticides in Soil and the Environment". Stratford-upon-Avon, UK, 1996. Stratford-upon-Avon: COST; 1996. p. 49-51.

23. Noble A. Partition coefficients (n-octanol-water) for pesticides. J Chromatogr 1993;642:3-14.

24. Laird DA, Koskinen WC. Triazine soil interactions. In: Baron HM, McFarland J, Burnside OC, editors. The Triazines Herbicides. Chapter 21. Amsterdam: Elsevier; 2008. p. 27599.

25. Moreau-Kervévan C, Mouvet C. Adsorption and desorption of atrazine, deethylatrazine and hydroxyatrazine by soil components. J Environ Qual 1998;27:46-53.

26. Lerch RN, Blanchard PE, Thurman EM. Contribution of hydroxylated atrazine degradation products to the total atrazine load in midwestern streams. Environ Sci Technol 1998;32:40-8

27. Abbt-Braun G, Frimmel FH. Basic characterization of Norwegian NOM samples - similarities and differences. Environ Int 1999;25:161-80.

28. Steelink C. Investigating humic acids in soils. Anal Chem 2002;74:327A-33A.

29. Shirshova Timofeevna L, Ghabbour EA, Davies G. Spectroscopic characterisation of humic acid fractions isolated from soil using different extraction procedures. Geoderma 2006;133:204-16.

30. Fingler S, Stipičević S, Drevenkar V. Sorption behaviour of chlorophenols and triazine herbicides in reference EUROSoils. Int J Environ Anal Chem 2004;84:83-93. 
Sažetak

\section{UTJECAJ ORGANSKIH I MINERALNIH SASTOJAKA TLA NA SORPCIJSKO PONAŠANJE} KLORFENOLNIH I TRIAZINSKIH MIKROZAGAĐIVALA

Uspoređena je sorpcija 2,4,6-triklorfenola, 2,3,4,6-tetraklorfenola i pentaklorfenola te različito supstituiranih triazinskih spojeva - klortriazina atrazina, metiltiotriazina ametrina, metoksitriazina atratona i razgradnih produkata atrazina hidroksiatrazina i didealkiliranog atrazina - u površinskom tlu i sedimentu vodonosnika prije i nakon uklanjanja organske tvari te u huminskoj kiselini. Izračunani su koeficijenti Freundlichove izoterme $K_{\mathrm{f}} \mathrm{i} 1 / n$ te izmjena slobodne energije $\left(\Delta G^{\circ}\right)$ za sve spojeve i sorbense. U skladu s pH-vrijednostima sorbensa u svim su sorpcijskim pokusima s nativnim tlom i sedimentom prevladavali klorfenolatni anioni i neutralni triazinski spojevi. U pokusima s huminskom kiselinom klorfenoli, atrazin i didealkilirani atrazin postojali su kao neutralne vrste, dok su hidroksiatrazin, atraton i ametrin bili većim dijelom protonirani. Sorpcija svih spojeva u prirodnom tlu i sedimentu uključuje uz hidrofobnu particiju i specifične polarnije interakcije ovisne o kiselosti/bazičnosti sorbata, specifičnim svojstvima organske tvari i mineralne površine sorbensa te o pH-vrijednosti sustava. Intenzitet sorpcije svih spojeva u sedimentu iz kojeg je uklonjena organska tvar bio je značajno veći od sorpcije u prirodnom sedimentu, što potvrđuje važnost i moguću dominantnu ulogu mineralne površine u sorpcijskom procesu. Intenzitet sorpcije klorfenola te klortriazina, metiltiotriazina i metoksitriazina u huminskoj kiselini korelirao je s hidrofobnosti spojeva. Veća sorpcija gotovo potpuno protoniranog hidroksiatrazina od hidrofobnijeg, ali neutralnog atrazina upućuje na različita reakcijska mjesta za ova dva spoja, a time i na različite mehanizme sorpcije u huminskoj kiselini.

KLJUČNE RIJEČI: ametrin, atraton, atrazin, didealkilirani atrazin, Freundlichova izoterma, hidroksiatrazin, huminska kiselina, klorfenolatni anioni, mineralna površina, organska tvar

\section{CORRESPONDING AUTHOR:}

\section{Sanja Stipičević}

Institute for Medical Research and Occupational Health

Ksaverska c. 2, POB 291, HR-10 001 Zagreb, Croatia

E-mail: stipicevic@imi.hr 